Нетепчук B. B. ${ }^{[1 ; 0 R C I D ~ I D: 0000-0002-5210-3373], ~}$ ст. викладач, Заслужений працівник освіти України

${ }^{1}$ Національний університет водного господарства та природокористування, м. Рівне

\title{
РОЗРОБКА МОДЕЛІ СИСТЕМИ УПРАВЛІННЯ ЗАКЛАДОМ ВИЩОЇ ОСВІТИ З ВИКОРИСТАННЯМ МЕТОДИКИ ПРОЦЕСНОГО МЕНЕДЖМЕНТУ ТА СТАНДАРТУ ISO 9001-2015
}

У статті розглянуто основні кроки методології моделювання бізнеспроцесу, проведено аналіз вимог міжнародного стандарту ISO 9001-2015 «Системи управління якістю. Вимоги» до побудови систем управління, змісту та послідовності основних робіт з розробки системи управління на прикладі моделі «Управляти вищим навчальним закладом». Розроблено авторську модель бізнес-процесу «Управляти вищим навчальним закладом» згідно вимог нотації IDEFO у трьох рівнях декомпозиції, сформульовано зміст основних результуючих та проміжних продуктів бізнес-процесів, що описують зміст процесу «Управляти вищим навчальним закладом».

Метою написання статті є візуалізація процесу формування моделі системи управління закладом вищої освіти 3 використанням методики процесного менеджменту та стандарту ISO-9001-2015, ідентифікація та опис основних результуючих продуктів діяльності закладу вищої освіти, переліку бізнес-процесів та взаємозв'язків між ними.

Запропонований автором алгоритм декомпозиції та візуалізація моделі управління закладом вищої освіти, як сукупністю бізнес-процесів у форматі IDEFO створює можливості для подальшого дослідження і опису змісту проміжних процесів і їх продуктів, формування та опису документованих інформаційних потоків, стандартизованого опису бізнеспроцедур, визначення та опису вимог до ресурсного забезпечення процесів системи управління.

Ключові слова: освіта; цілі; компетентності; модель; бізнес-процес; система управління якістю; результуючий продукт діяльності; принципи менеджменту якості; графічна мова IDF 0.

Постановка завдання. Метою написання статті $€$ візуалізація процесу формування моделі системи управління закладом вищої освіти з використанням методики процесного менеджменту та стандарту ISO 9001-2015.

Аналіз останніх досліджень і публікацій. Ціль (мета) ідеальний і бажаний образ майбутнього результату діяльності, який породжується свідомістю і детермінує сам процес [6, С. 327]. 
3 метою конкретизації змісту академічного визначення терміну «ціль» трансформуємо термін «бажаний образ майбутнього результату діяльності» у термін «результуючий продукт діяльності» закладу вищої освіти.

Якість продукції та послуг організації - результуючого продукту діяльності - визначають їх здатністю задовольняти замовників, а також передбаченим і непередбаченим впливом на відповідні зацікавлені сторони.

Про доцільну корисність стандарту ISO 9001 [10] для розробки моделі системи управління закладом вищої освіти свідчить багаторічна статистика. Стандарт ISO 9001 - єдиний стандарт, що внесений до Книги рекордів Гіннеса як найбільш широко застосовний нормативний документ у світі. Понад 1,3 млн організацій у 187 країнах світу впровадили і сертифікували власні Системи управління якістю згідно з вимогами цього стандарту. В Україні сертифіковано близько 1300 організацій, з них приблизно 30 вишів провели сертифікацію навчального, виховного і наукового процесів, в тому числі: Університет економіки і права «Крок», Університет імені Альфреда Нобеля (м. Дніпро), Східноукраїнський національний університет імені Володимира Даля, Інститут післядипломної освіти керівних працівників водного транспорту в м. Одеса, Інститут інвестиційного менеджменту, Європейський університет та інші.

Стандарти ISO 9000 та ISO 9001 у своїх формулюваннях змісту термінів, що використовують в описі систем управління та формулюванні вимог до систем управління якістю особливу увагу звертають на зміст вимог до результуючих продуктів діяльності організації (підприємства) та їх прогнозованої спроможності задовольняти попередньо обумовлені потреби споживача.

Питання змісту результатів діяльності вищої школи, в тому числі в контексті компетентності випускника, зміст термінів, що визначають цілі навчального процесу та питання методики викладання у вищій школі, розглядали у своїх роботах Каплінський В. В., Прищак М. Д., Синявський В. В., Сергєєнкова О. П., Малофіїк Ф.В., Вітвицька С. С., Субіна О. О., Кремень В.Г. та інші вітчизняні і зарубіжні вчені.

Питання вдосконалення і розвитку вищої школи нині врегульовано Постановою Кабінету Міністрів України від 3.11.1993 р. N 896 «Про Державну національну програму «Освіта» («Україна XXI століття»), Законом України «Про вищу освіту» [4], Указом Президента України «Про Національну стратегію розвитку освіти в 
Україні на період до 2021 року» [7], Стратегією розвитку вищої освіти в Україні на 2021-2031 роки [8].

У переліку основних «проблем, викликів та ризиків», що відбуваються в нашій державі, вищезазначені документи зазначають:

- відсутність цілісної системи виховання, фізичного, морального і духовного розвитку і соціалізації дітей та молоді;

- падіння суспільної моралі, що призвело до бездуховності, низької культури поведінки частини учнівської та студентської молоді» [7].

Національна стратегія розвитку освіти в Україні на 2021-2031 роки на основі аналізу сучасного стану розвитку освіти орієнтує зосередити зусилля органів управління освітою, науковометодичних служб за підтримки всього суспільства на реалізацію стратегічних напрямів розвитку освіти, подоланні наявних проблем, виконанні перспективних завдань, серед яких першим пунктом зазначено оновлення цілей і змісту освіти на основі компетентнісного підходу та особистісної орієнтації, урахування світового досвіду та принципів сталого розвитку.

Варто зауважити, що Закон України «Про вищу освіту» [4] у своєму змісті упускає формулювання змісту цілі діяльності закладів вищої освіти і обмежується формулюванням основних завдань (ст. 26). Даний Закон також не регламентує вимог щодо формулювання вищим навчальним закладом у своєму Статуті цілей діяльності, переліку і змісту результуючих продуктів своєї діяльності.

Часткову конкретизацію кінцевого результату, цілей процесу навчання і виховання у системі вищої школи, що здійснює підготовку фахівців за освітнім рівнем «бакалавр», можна віднайти у Стандартах вищої освіти України за галузями знань і спеціальностями. Наприклад, Стандарт вищої освіти України за галуззю знань «Управління та адміністрування» спеціальності 073 «Менеджмент» стверджує ціль навчання: «Підготовка фахівців, здатних вирішувати практичні проблеми та складні спеціалізовані задачі, що характеризуються комплексністю та невизначеністю умов, у сфері управління організаціями та їх підрозділами» [5].

Конкретизація цілі навчання як бажаного кінцевого стану діяльності навчального закладу/підрозділу також частково зазначена у формулюванні інтегральної та загальних компетентностей випускника узагальнюючим терміном «здатність» та у нормативних результатах навчання термінами «знати», «демонструвати», «вміти», «виконувати». 
При цьому у зазначених формулюваннях простежується прагнення розробників Стандарту інтегрувати зміст нормативних результатів навчання із категоріями «вміння та навички» і «знання та вміння». При цьому, в сучасній педагогічній теорії осмислення ролі понять «знання», «вміння» та «навички» ускладнене через:

- нечітке розмежування в педагогічній теорії термінів «уміння» та «навички»;

- відсутність чіткого теоретичного обґрунтування логіки взаємозв'язку вмінь та знань [2].

Закон України «Про вищу освіту» [4] у змісті результатів навчання зазначає, окрім наявності у випускника знань, умінь і навичок, також такі компетентності, як способи мислення, погляди, цінності, інші особисті якості, які можна ідентифікувати, спланувати, оцінити і виміряти та які особа здатна продемонструвати після завершення освітньої програми або окремих освітніх компонентів. Конкретизація зазначеного у змісті Стандарту вищої освіти України за галуззю знань «Управління та адміністрування» спеціальності 073 «Менеджмент» $€$ відсутня або ж невизначена.

Стратегією розвитку вищої освіти в Україні на 2021-2031 роки, зазначено мету вищої освіти: «..є здобуття особою високого рівня наукових (творчих, мистецьких) професійних і загальних компетентностей, які необхідні для діяльності за певною спеціальністю чи в певній галузі знань».

Невизначеність формулювання мети освіти та виховання $€$ характерною не тільки для освітніх закладів. Вона також не сформульована на рівні державних нормативних документів, оскільки їі зміст в різних документах звучить неоднозначно. Відсутність чіткості, прогностичності і перспективності у визначенні мети виховання молоді і мети освіти в Україні не сприяє консолідації зусиль всіх суб'єктів на її досягнення.

Для конкретизації змісту формулювання основних результуючих продуктів діяльності закладів вищої освіти, забезпечення їх дієвості (вимірність результату), оцінки результативності та ефективності доцільно застосувати у розробці та описі систем управління навчальним закладом методики процесного менеджменту.

Виклад основного матеріалу. У Національному Стандарті України ДСТУ ISO/IEC/IEEE 15288:2016 (ISO/IEC/IEEE 15288:2015, IDT): «Інженерія систем і програмного забезпечення. Процеси життєвого циклу систем» [7] наводиться текстовий опис бізнеспроцесу «Управляти якістю», що має ціль - забезпечити 
відповідність продуктів, послуги і реалізації процесу управління якістю організаційним, проєктним цілям управління якістю та досягнення задоволеності замовника.

Застосування стандартів серії ISO для розробки i удосконалення систем управління закладом вищої освіти дозволяє ідентифікувати перелік і зміст бізнес-процесів, зміст результуючих та проміжних продуктів, вхідних потоків та регламентів, що деталізують зміст робіт з розробки і функціонування системи управління.

Ідеєю реформування вищої освіти в частині забезпечення професійної компетентності особистості $є$ підготовка кваліфікованих кадрів, здатних до творчої праці, професійного розвитку, освоєння й впровадження наукоємних та інформаційних технологій, конкурентоспроможних на ринку праці.

Для забезпечення якості освітньої підготовки та професійної компетентності особистості Міністерством освіти та науки України запроваджено перелік стандартних вимог щодо оцінки підготовки фахівців шляхом акредитації відповідності освітньої програми та освітньої діяльності закладу вищої освіти за цією освітньою програмою за критеріями [11]:

$\checkmark$ Проєктування та цілі освітньої програми.

$\checkmark$ Структура та зміст освітньої програми.

$\checkmark$ Доступ до освітньої програми та визнання результатів навчання.

$\checkmark$ Навчання і викладання за освітньою програмою.

$\checkmark$ Контрольні заходи, оцінювання здобувачів вищої освіти та академічна доброчесність.

$\checkmark$ Людські ресурси.

$\checkmark$ Освітнє середовище та матеріальні ресурси.

$\checkmark$ Внутрішнє забезпечення якості освітньої програми.

$\checkmark$ Прозорість та публічність.

$\checkmark$ Навчання через дослідження.

В практиці діяльності 3ВО, окрім вищезгаданих дій 3 вдосконалення змісту і форм навчального процесу, забезпечення кваліфікації науково-педагогічного персоналу не можна не відзначити прагнення забезпечити створення сучасної наукової продукції, відповідної матеріально-технічної бази навчального процесу, забезпечити цінову конкурентоздатність освітніх послуг, відповідність функціонування закладу правовим вимогам.

Вищенаведений аналіз змісту вимог щодо оцінки підготовки фахівців вищим навчальним закладом дозволяє стверджувати, що сучасні вітчизняні прагнення вдосконалити якість освіти, як правило, орієнтовані на внутрішній аспект - забезпечити відповідність 
діяльності ЗВО нормі, стандарту, специфікації (зміст освіти, рівень підготовки студента, викладача, інформаційно-методичний супровід, матеріально-технічне забезпечення підготовки, освітні технології, наукова діяльність).

«Якість освіти» за своїм змістовим наповненням надзвичайно ємне і стосується не лише освіти, а й різних соціокультурних чинників та факторів, поза впливом яких освіта не існує, існувати та розвиватися не може» [3]. На якість вищої освіти також впливають здібності студентів, мотивація учасників навчального процесу до успішної діяльності, наявність у закладі чіткої системи управління якістю освіти.

Умовний розподіл учасників навчального процесу на відповідальних за створення якості та на клієнтів, прагнення мінімізації відмінності між стандартом і фактичним результатом діяльності ростить бар'єри між безпосередніми учасниками головного процесу діяльності навчального закладу - студентами, викладачами та адміністрацією.

Тому формулювання критеріїв оцінки якості освіти не помічає проблеми забезпечення якості освіти через попередньо обумовлені, сформульовані і діючі моделі управління освітнім процесом, як форму вираження відповідальності вищого керівництва на макро- чи мікрорівні 3 метою забезпечення гармонізації ії якісних характеристик, що спрямовані на задоволення потреб не так держави і не лише їі, а передусім запитів самої людини. Важливо, щоб формулювання мети вищої освіти у частині розвитку особистості передбачало не тільки ії професійну компетентність, а й компетентність духовну та соціальну як основу ефективної взаємодії людини у світі.

Забезпечення якості освіти слід шукати у застосуванні в управлінні 3 ВО положень системного менеджменту із використанням процесного підходу, орієнтації діяльності університету на задоволення потреб суспільства як головного споживача і матеріального утримувача його діяльності, продукування конкурентоспроможного фахівця, здатного легко адаптуватися в економічно-соціальному просторі європейських країн.

Такою моделлю може бути система управління якістю, що описана Міжнародними стандартами серії ISO-9000. Процедура впровадження системи управління якістю $€$ типовою для всіх організацій та передбачає виконання наступного переліку управлінських дій [10]: 
$\checkmark$ ідентифікувати потреби і очікування споживачів та інших зацікавлених сторін (4, п. 7.2.1а);

$\checkmark$ розробити політику та цілі організації у сфері якості (4, п. 5.1в);

$\checkmark$ ідентифікувати процеси, необхідні для системи менеджменту якості, та їх застосування у всій організації (4, п. 4.1 а);

$\checkmark$ ідентифікувати і визначити необхідні ресурси та забезпечити їх наявність для досягнення цілей в області якості (4, п. 6.1а);

$\checkmark$ розробити критерії та методи, необхідні для забезпечення результативності як при здійсненні цих процесів, так і при управління ними кожного із процесів $(4, \pi .4 .1 \mathrm{c})$;

$\checkmark$ застосовувати дані цих вимірювань для визначення результативності і ефективності кожного із процесів;

$\checkmark$ визначити засоби, необхідні для попередження виникнення невідповідностей та усунення їх причин (4, п. 8.5.3);

$\checkmark$ розробити і застосувати процес постійного покращення системи менеджменту якості $(4$, п. 8.1c).

Кожен із вищезазначених етапів $€$ обов'язковим для всього персоналу навчального закладу. Їх виконання дозволить кожному учаснику навчального процесу усвідомити персональну роль у створенні доданої споживчої цінності у кінцевому продукті діяльності університету та відповідальність за результати праці.

Програмна заява вищого керівництва закладу освіти щодо Політики та цілей у сфері якості може включати:

$\checkmark$ стратегію закладу щодо якості і стандартів;

$\checkmark$ опис основних продуктів діяльності та критерії їх оцінки;

$\checkmark$ організацію системи забезпечення якості;

$\checkmark$ відношення між викладанням та науково-дослідною роботою у закладі;

$\checkmark$ відповідальність кафедр, шкіл, факультетів та інших організаційних одиниць, осіб у забезпеченні якості бізнеспроцесів;

$\checkmark$ залучення студентів до забезпечення якості освітнього процесу;

$\checkmark$ способи втілення політики, їі моніторингу та перегляду.

Традиційно споживачем результуючого продукту навчального процесу ВНЗ розглядають управлінські, виробничо-господарські та сервісні організації. Тому у переліку головних задач діяльності ЗВО $€$ забезпечення галузей національної економіки кадрами, які відповідають вимогам нових економічних відносин.

Особливістю сьогоднішнього економічного середовища $\epsilon$ хаотичність, глобалізація економік та культур, невизначеність та швидкоплинність потреб споживача, стрибкоподібність розвитку 
можливостей і потреб служб сервісу та виробництва [8]. В останні роки складність і суперечливість економічного середовища для 3 ВО стала ще більш явною. Причиною цього $є$ те, що 50-60\% студентів вузів державної форми власності, а у закладах недержавної форми власності всі $100 \%$ студентів виступають в ролі замовників, споживачів та головного джерела фінансування навчального процесу - продукту основної діяльності навчального закладу.

Окрім того, навчальний процес - це послуга, процес створення і надання якої передбачає обов'язкову участь споживача у створенні самої послуги. Головними споживачами і особами зацікавленими результуючим продуктом освітнього процесу є студенти, власники і керівники бізнесу, викладачі, керівники навчальних закладів, громадськість, уряд та органи місцевого самоврядування.

Тому, керуючись визначенням змісту менеджменту якості, філософія управління якістю освітніх послуг повинна бути орієнтована на створення форм і механізмів, які дозволять визначати і оперативно коригувати цілі, залишаючи їх єдиними і спільними для всіх зацікавлених сторін і учасників даного процесу, в тому числі для студентів.

Формулювання і розвиток цілей у сфері якості має за мету об'єднати всіх учасників навчального процесу через орієнтацію управлінських дій на створення середовища, що відповідає наступним умовам:

$\checkmark$ студенти, що навчаються, мають бути впевнені, що навчання за обраною спеціальністю розширюватиме їхні знання, навички та дозволить їм мати роботу і працювати ефективно;

$\checkmark$ керівники підприємств, власники бізнесу (роботодавці) повинні знати стандарти, яким керуються навчальні заклади при складанні навчального плану, робочих програм для підготовки їх майбутніх працівників. Це дозволить їм займати активну позицію у внесенні пропозицій із вдосконалення навчального процесу;

$\checkmark$ викладачі повинні бути впевнені, що курси та програми задовольняють потреби студентів та цінуються підприємствами;

$\checkmark \quad$ громадськість повинна бути впевнена у позитивному впливі результатів діяльності навчального закладу у розбудову регіональної громади та суспільства в цілому. 


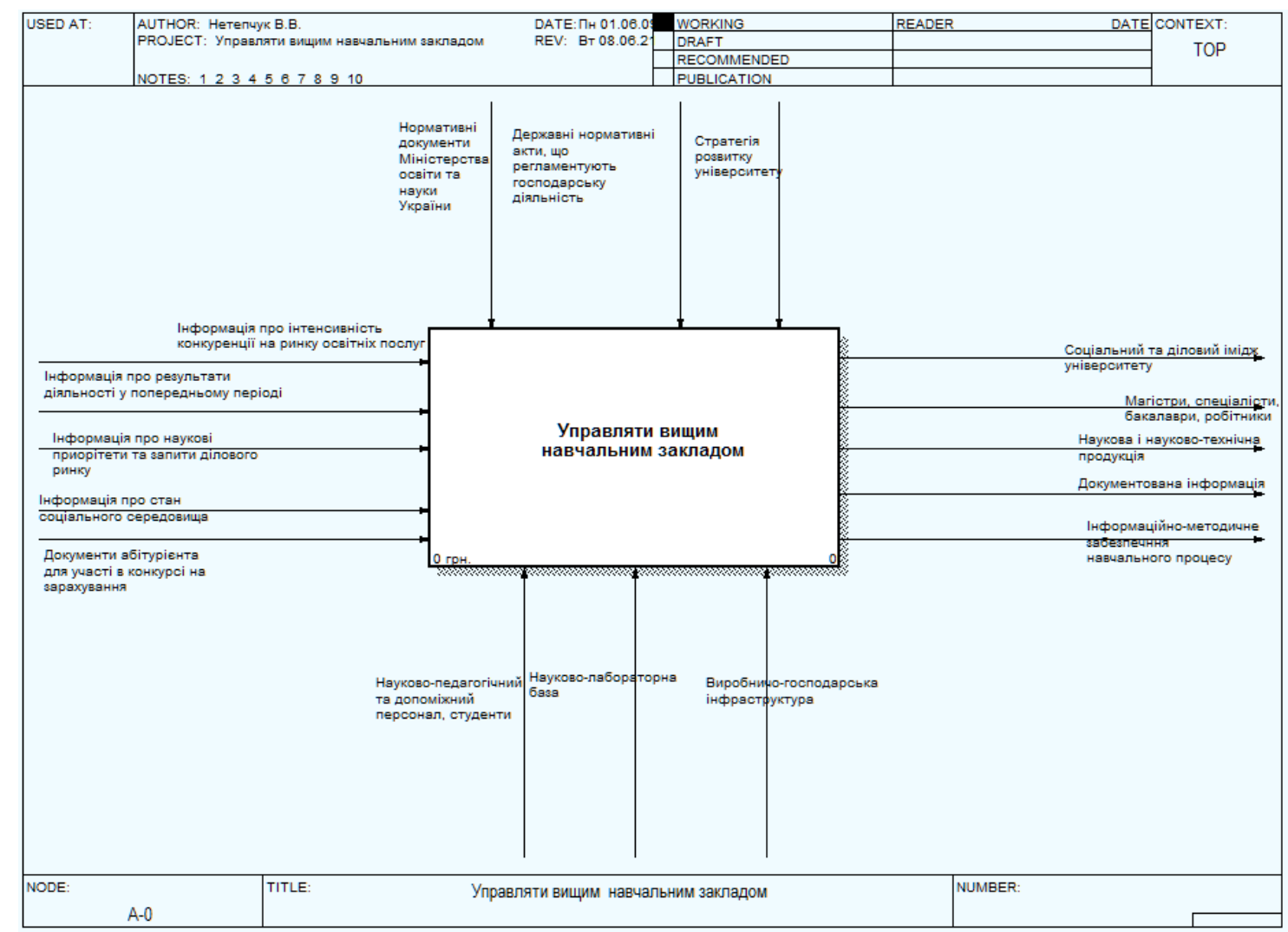

Рис. 1. Модель бізнес-процесу «Управляти вищим навчальним закладом»

Застосування процесного підходу в управлінні вищим навчальним закладом передбачає насамперед розгляд будь-якої діяльності як процесу (рис. 1), вимоги до опису якого у нотації IDFO передбачають ідентифікацію основних продуктів діяльності, споживачів та їх вимог до якісних характеристик основного продукту діяльності університету, ідентифікацію переліку та змісту вимог до вхідних потоків процесу, вимог до ресурсного забезпечення процесу та визначення і документований опис регламентів.

Сформулюємо основні продукти бізнес-процесу «управляти діяльністю закладу вищої освіти»:

а) випускник (доктор наук, кандидат наук, магістр, спеціаліст, бакалавр, молодший спеціаліст, робітник) - особистість, суб'єкт діяльності і суспільних відносин, носій духовної, соціальної та професійної компетентності, що вільно володіє стандартами рольової професійної поведінки.

Головними критеріями, що вирізняють випускника університету на ринку праці $є$ :

$\checkmark$ духовна, соціальна та професійна компетентність як основа фахової підготовки;

$\checkmark$ вміння гармонізувати свої дії з довкіллям; 
$\checkmark$ досконале володіння українською мовою, демонстрація національної свідомості, активної громадянської позиції, високих моральних якостей та духовних запитів;

$\checkmark$ усвідомлене формулювання процедури розвитку власного «Я», здатність до сприйняття та використання на практиці нових наукових ідей, технічних інструментів і методів виробництва, розвитку новаторських здібностей, ініціативи та підприємливості;

$\checkmark$ вільне володіння сучасним прикладними комп'ютерними програмами за напрямками підготовки;

$\checkmark$ розуміння та здатність до спілкування кількома іноземними мовами;

б) наукова i науково-технічна продукція фундаментальних та прикладних наукових досліджень: дисертації; монографії; наукові школи; наукові доктрини і концепції; патенти на нові технічні рішення; наукові відкриття; інноваційні проєкти; наукові збірники, доповіді, статті; науково-методичні розробки; нормативно-правові документи; наукові звіти; проєктно-конструкторська і технологічна документація; інші нові наукові знання, інтелектуальні продукти наукового спрямування, які можуть виступати об'єктами права інтелектуальної власності;

в) діловий імідж - позиціювання та сприйняття університету як суб'єкта ділової активності, що забезпечує повноту, своєчасність та якість обумовлених і очікуваних громадянами соціальної спільноти освітньо-наукових послуг завдяки фундаментальній і прикладній компетентності згуртованої і професійної команди науковців, педагогів, які утверджують та розвивають у суспільстві фахові, моральні і вольові якості молодої людини, спираючись на духовні і культурні цінності національної та світової культури;

г) соціальний імідж - позиціювання та сприйняття закладу вищої освіти як національного центру освіти, науки і культури, що виховує свідомого громадянина-патріота Української держави, активного провідника національної ідеї, представника української національної еліти;

д) документована інформація - нормативні та нормативнотехнічні документи, положення, настанови, концепції, плани, звіти, протоколи, інформація, дані, що у своїй загальній та вибірковій сукупності інформують про розвиток закладу вищої освіти, його забезпечення ресурсами, стан освітньо-виховного процесу та наукової діяльності, стан контролю, результативності та 
ефективності коригуючих і попереджуючих дій щодо покращення системи управління якістю в університеті.

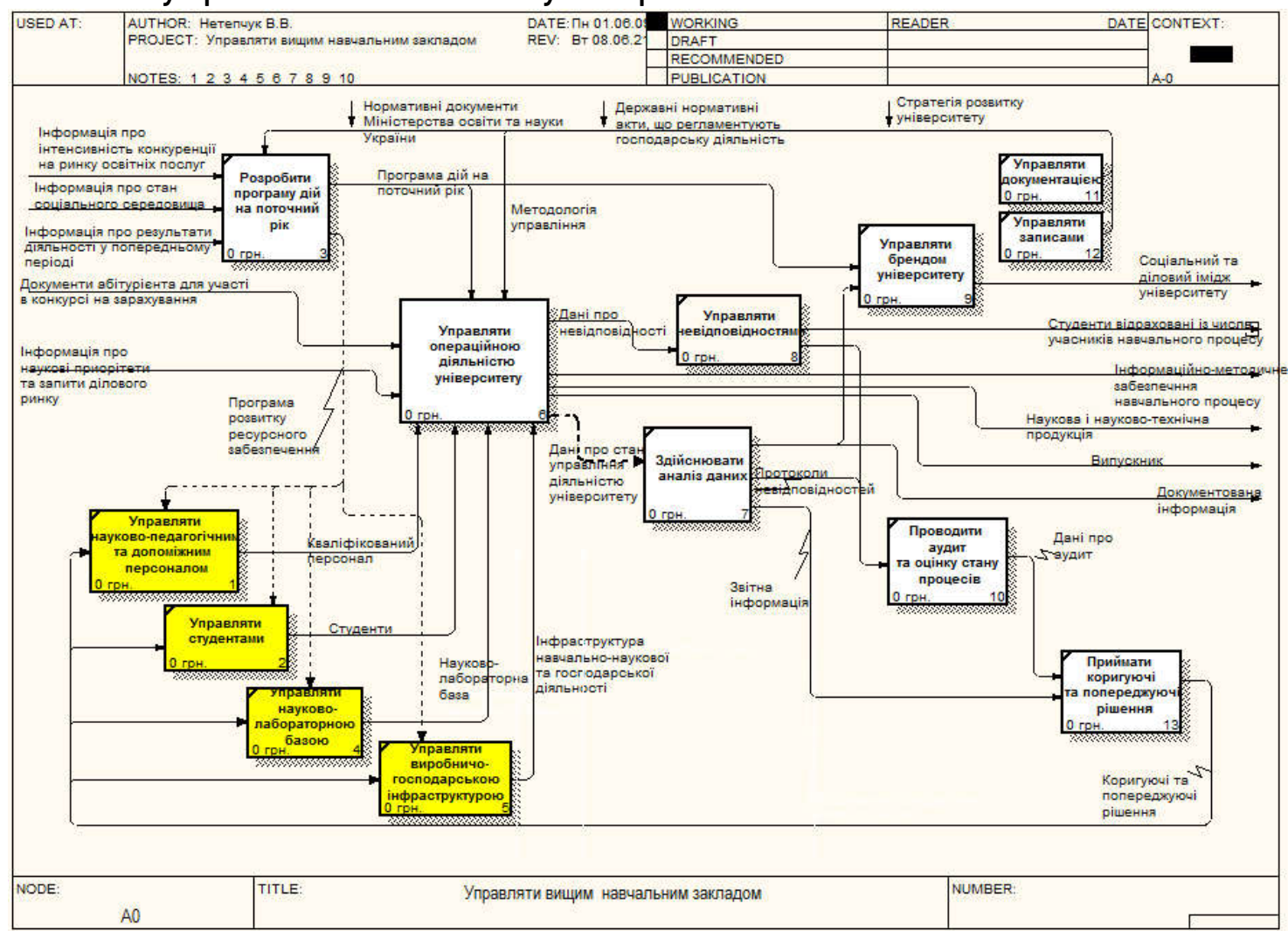

Рис. 2. Декомпозиція моделі «Управляти вищим навчальним закладом» у нотації IDFO

Документований опис змісту основних продуктів діяльності університету, окрім визначення, також передбачає формулювання їх оціночних критеріїв та головних споживачів зазначених продуктів.

3 метою деталізації змісту процесу «Управляти вищим навчальним закладом» проведемо його декомпозицію на сукупність бізнес-процесів (рис. 2). При розробці і візуалізації контекст-моделі бізнес-процесу скористаємося вимогами стандарту ISO 9001-2015. На моделі відображено сукупність бізнес-процесів, що описують управлінський цикл за методикою Е. Демінга, процеси ресурсного забезпечення, оціночні та організаційно-управлінські бізнеспроцеси. Зазначений перелік процесів поєднаний у ланцюг взаємозв'язків, де вихідний продукт одного процесу $є$ вхідним потоком для наступного.

Зазначена методика опису та візуалізації сприяє менеджменту закладу вищої освіти досятти поставленої мети - забезпечити опис кількісних та якісних вимог до основних і проміжних продуктів діяльності, конкретизувати вимоги і забезпечити відповідність ресурсного забезпечення бізнес-процесів, оптимізувати ефективність і результативність їх протікання, забезпечити високий 
ступінь задоволеності усіх зацікавлених сторін у результатах діяльності закладу вищої освіти.

Модель бізнес-процесу, що деталізує зміст сукупності дій «Управляти операційною діяльністю», візуалізуємо на рис. 3.

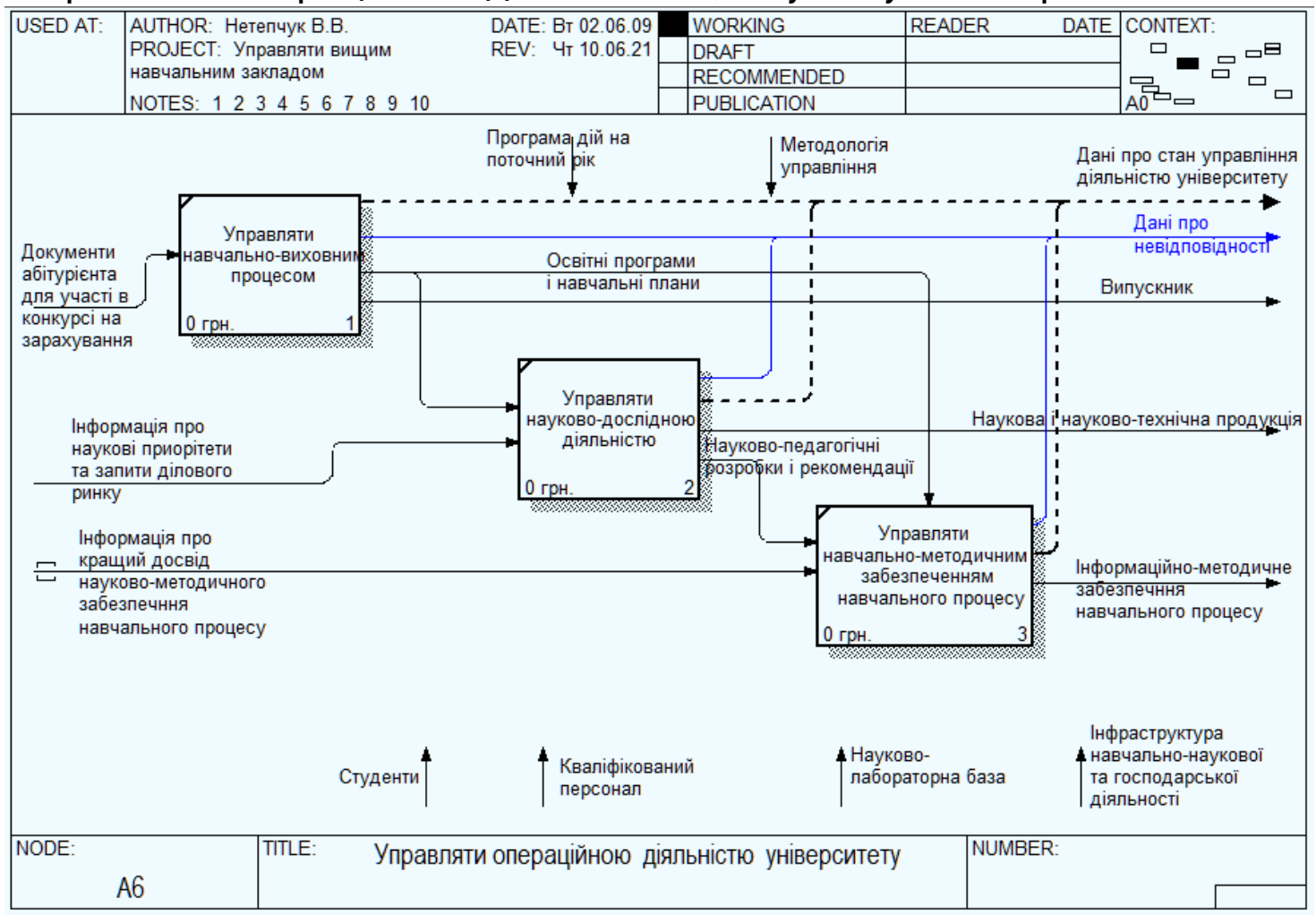

Рис. 3. Модель бізнес-процесу «Управляти операційною діяльністю»

Висновки. Звертаючись до змісту стандарту ISO 9000 [9], зазначимо, що зміст діяльності закладу вищої освіти визначає система управління (management system) - сукупність взаємопов'язаних або взаємодійних елементів організації, що забезпечують зміст та порядок формування політики, установлення цілей і процесів, щоб досягати визначених цілей. Система управління якістю (quality management system) є частиною системи управління вищим навчальним закладом стосовно якості [9].

Заклади вищої освіти для збереження своєї життєздатності на ринку освітніх послуг прагнуть забезпечити відповідність освітньої програми та освітньої діяльності за цією освітньою програмою, вдосконалити якість освіти, яку вони пропонують студентам.

Наведений у статті алгоритм візуалізації та декомпозиції моделі управління $3 В 0$ створює можливості для подальшого дослідження і опису змісту проміжних бізнес-процесів та їх продуктів, формування та опису документованих інформаційних потоків, провести стандартизований опис бізнес-процедур, визначити та описати вимоги до ресурсного забезпечення процесів системи управління, 
що створить надійні передумови для розробки системи управління та іï сертифікації на відповідність ДСТУ ISO 9001:2015 «Системи управління якістю. Вимоги» [10].

Спроможність університету сформулювати в освітніх програмах чітко визначені очікувані результати навчання; забезпечити готовність, бажання і здатність науково-педагогічного персоналу створити такі умови, які б допомагали студентам досяти декларованих результатів від навчання у ЗВО; забезпечити повне, вчасне і відчутне визнання внеску у здійснювану роботу тієї частини персоналу, яка демонструє видатну майстерність, прекрасні фахові знання, відданість справі, дозволяє стверджувати про переконливе прагнення вищого керівництва закладу освіти підтримати статус та ділове визнання освітньої установи у Європейському просторі вищої освіти, забезпечити якісне управління нею.

1. Про Державну національну програму «Освіта» («Україна XXI століття») : Постанова Кабінету Міністрів України від 3.XI.1993 p. N 896. URL: https://zakon.rada.gov.ua/laws/show/896-93-\%D0\%BF\#Text. (дата звернення: 10.04.2021). 2. Каплінський В. В. Методика викладання у вищій школі : навч. посіб. Вінниця : ТОВ «Ніланд ЛТД», 2015. 224 с. 3. Прищак М. Д., Залюбівська О. Б. Педагогіка, психологія та методика викладання у вищій школі : курс лекцій. Вінниця : ВНTУ, 2019. 150 с. 4. Про вищу освіту : Закон України. URL: https://zakon.rada.gov.ua/laws/show/1556-18\#Text (дата звернення: 10.04.2021). 5. Стандарт вищої освіти України за галуззю знань «Управління та адміністрування» спеціальності 073 «Менеджмент». URL: https://mon.gov.ua/storage/app/media/vishcha-

osvita/zatverdzeni\%20standarty/12/21/073-menedzhment-bakalavr.pdf. (дата звернення: 10.04.2021). 6. Авт.-уклад. Синявський В. В., Сергєєнкова О. П. Психологічний словник / за ред. Н. А. Побірченко. URL: https://elibrary.kubg.edu.ua/id/eprint/5980/3/0_Serhieienkova_IL.pdf (дата звернення: 10.04.2021). 7. Про Національну стратегію розвитку освіти в Україні на період до 2021 року : Указ Президента України. URL: https://zakon.rada.gov.ua/laws/show/344/2013\#Text. (дата звернення: 10.04.2021). 8. Стратегія розвитку вищої освіти в Україні на 2021-2031 роки. URL: https://mon.gov.ua/storage/app/media/rizne/2020/09/25/rozvitku-vishchoi-osviti-vukraini-02-10-2020.pdf (дата звернення: 10.04.2021). 9. ДСТУ ISO 9000:2015 (ISO 9000:2015, IDT). Системи управління якістю. Основні положення та словник термінів. Київ : ДП «УкрНДНЦ», 2016. 10. ДСТУ ISO 9001:2015 (ISO 9001:2015, ID). Системи управління якістю. Вимоги. Київ : ДП «УкрНДНЦ», 2016. 11. Про затвердження Положення про акредитацію освітніх програм, за якими здійснюється підготовка здобувачів вищої освіти : Наказ Міністерства освіти і науки України від 11.07.2019 № 977.

\section{REFERENCES:}

1. Pro Derzhavnu natsionalnu prohramu «Osvita» («Ukraina XXI stolittia») : Postanova Kabinetu Ministriv Ukrainy vid 3.Khl.1993 r. $N$ 896. URL: 
https://zakon.rada.gov.ua/laws/show/896-93-\%D0\%BF\#Text. (data zvernennia: 10.04.2021). 2. Kaplinskyi V. V. Metodyka vykladannia u vyshchii shkoli : navch. posib. Vinnytsia : TOV «Niland LTD», 2015. 224 s. 3. Pryshchak M. D., Zaliubivska O. B. Pedahohika, psykholohiia ta metodyka vykladannia u vyshchii shkoli : kurs lektsii. Vinnytsia : VNTU, 2019. 150 s. 4. Pro vyshchu osvitu : Zakon Ukrainy. URL: https://zakon.rada.gov.ua/laws/show/1556-18\#Text (data zvernennia: 10.04.2021). 5. Standart vyshchoi osvity Ukrainy za haluzziu znan «Upravlinnia ta administruvannia» spetsialnosti 073 «Menedzhment». URL: https://mon.gov.ua/storage/app/media/vishchaosvita/zatverdzeni\%20standarty/12/21/073-menedzhment-bakalavr.pdf. (data zvernennia: 10.04.2021). 6. Avt.-uklad. Syniavskyi V. V., Serhieienkova O. P. Psykholohichnyi slovnyk / za red. N. A. Pobirchenko. URL: https://elibrary.kubg.edu.ua/id/eprint/5980/3/0_Serhieienkova_IL.pdf (data zvernennia: 10.04.2021). 7. Pro Natsionalnu stratehiiu rozvytku osvity v Ukraini na period do 2021 roku : Ukaz Prezydenta Ukrainy. URL: https://zakon.rada.gov.ua/laws/show/344/2013\#Text. (data zvernennia: 10.04.2021). 8. Stratehiia rozvytku vyshchoi osvity v Ukraini na 2021-2031 roky. URL: https://mon.gov.ua/storage/app/media/rizne/2020/09/25/rozvitku-vishchoi-osviti-vukraini-02-10-2020.pdf (data zvernennia: 10.04.2021). 9. DSTU ISO 9000:2015 (ISO 9000:2015, IDT). Systemy upravlinnia yakistiu. Osnovni polozhennia ta slovnyk terminiv. Kyiv : DP «UkrNDNTs», 2016. 10. DSTU ISO 9001:2015 (ISO 9001:2015, ID). Systemy upravlinnia yakistiu. Vymohy. Kyiv : DP «UkrNDNTs», 2016. 11. Pro zatverdzhennia Polozhennia pro akredytatsiiu osvitnikh prohram, za yakymy zdiisniuietsia pidhotovka zdobuvachiv vyshchoi osvity : Nakaz Ministerstva osvity i nauky Ukrainy vid 11.07.2019 № 977.

Netepchuk V. V. ${ }^{[1 ; 0 R C I D ~ I D: 0000-0002-5210-3373], ~}$ Senior Lecturer, Honoured Education Worker of Ukraine

${ }^{1}$ National University of Water and Environmental Engineering, Rivne

\section{DEVELOPMENT OF A MODEL OF THE MANAGEMENT SYSTEM OF HIGHER EDUCATION INSTITUTION USING THE PROCEDURE MANAGEMENT METHODOLOGY AND ISO 9001-2015 STANDARD}

The article considers the main steps of the business process modeling methodology, analyzes the requirements of the international standard ISO 9001-2015 "Quality Management Systems. Requirements "to the construction of management systems, content and sequence of the main work on the development of the management system on the example of the model" Manage higher education institution".

The author's model of the business process "Manage a higher education institution" according to the requirements of IDEFO notation in three levels of decomposition is developed, the content of the main result and intermediate products of business processes describing the content of the process "Manage higher education institution" is formulated. 
The purpose of this article is to visualize the process of forming a model of higher education institution management system using process management techniques and IS0-9001-2015, identification and description of the main results of higher education, a list of business processes and relationships between them.

The author's proposed decomposition algorithm and visualization of the higher education institution management model as a set of business processes in IDEFO format creates opportunities for further research and description of intermediate processes and their products, formation and description of documented information flows, standardized description of business procedures, definition and description requirements for resource provision of management system processes.

Keywords: education; goals; competencies; model; business process; quality management system; the resulting product; the principles of quality management; graphic language IDF0.

Нетепчук B. В. [1; ORCID ID: 0000-0002-5210-3373], ст. преподаватель, Заслуженный работник образования Украины

${ }^{1}$ Национальный университет водного хозяйства и природопользования, г. Ровно

\section{РАЗРАБОТКА МОДЕЛИ СИСТЕМЫ УПРАВЛЕНИЯ ВЫСШИМ УЧЕБНЫМ ЗАВЕДЕНИЕМ С ИСПОЛЬЗОВАНИЕМ МЕТОДИКИ ПРОЦЕССНОГО МЕНЕДЖМЕНТА И СТАНДАРТА ISO 9001-2015}

В статье рассмотрены основные шаги методологии моделирования бизнес-процесса, проведен анализ требований международного стандарта ISO 9001-2015 «Системы управления качеством. Требования.» к построению систем управления, содержания и последовательность основных работ по разработке системы управления на примере модели «Управлять высшим учебным заведением». Разработана авторская модель бизнес-процесса «Управлять высшим учебным заведением» согласно требованиям нотации IDEFO в трех уровнях декомпозиции, сформулированы содержание основных результирующих и промежуточных продуктов бизнес-процессов, описывающих содержание процесса «Управлять высшим учебным заведением».

Целью написания статьи является визуализация процесса формирования модели системы управления учреждением высшего образования с использованием методики процессного менеджмента и стандарта ISO-9001-2015, идентификация и описание основныX результирующих продуктов деятельности высшего учебного заведения, перечень бизнес-процессов и взаимосвязей между ними.

Предложенный автором алгоритм декомпозиции и визуализация модели управления высшим учебным заведением как совокупности 
бизнес-процессов В формате IDEFO создает возможности для дальнейшего исследования и описания содержания промежуточных процессов и их продуктов, формирования и описания документированных информационных потоков, стандартизированного описания бизнес-процедур, определения и описания требований к ресурсному обеспечению процессов системы управления.

Ключевые слова: образование; цели; компетентности; модель; бизнес-процесс; система управления качеством; результирующий продукт деятельности; принципы менеджмента качества; графический язык IDFO.

Отримано: 30 квітня 2021 р. Прорецензовано: 05 травня 2021 р. Прийнято до друку: 25 червня 2021 р. 